\title{
PENGARUH PENAMBAHAN BIOFLOK DENGAN DOSIS BERBEDA TERHADAP PERTUMBUHAN BENIH UDANG WINDU (Penaeus monodon FABRICIUS 1798)
}

\section{INFLUENCE OF BIOFLOC ADDITION WITH DIFFERENT DOSAGES ON THE GROWTH OF TIGER SHRIMP JUVENILE (Penaeus monodon Fabricius 1798)}

\author{
Ilham Zulfahmi ${ }^{1}$, Muhammad Syahimi ${ }^{2}$, Muliari ${ }^{2}$ \\ ${ }^{I}$ Program Studi Biologi, Fakultas Sains dan Teknologi, Universitas Islam Negeri Ar-Raniry. Kota Pelajar dan \\ Mahasiswa, Darussalam, Banda Aceh 23111 \\ ${ }^{2}$ Program Studi Budidaya Perairan Universitas Almuslim. Jalan Almuslim, Matangglumpangdua, Paya Cut, \\ Peusangan, Kabupaten Bireuen, Aceh 24261 \\ *Corresponding author: ilhamgravel@yahoo.com
}

Naskah Diterima: 8 Februari 2017; Direvisi: 28 September 2017; Disetujui: 2 Oktober 2017

\begin{abstract}
Abstrak
Penelitian ini bertujuan untuk mengetahui pengaruh penambahan bioflok terhadap pertumbuhan dan kelangsungan benih udang windu. Penelitian dilakukan selama 30 hari dari Juni hingga Juli 2016 di Laboratorium Program Studi Budidaya Perairan Universitas Almuslim Bireuen. Wadah pemeliharaan berupa akuarium berukuran $50 \times 30 \times 40 \mathrm{~cm}^{3}$ bervolume $10 \mathrm{~L}$ dengan padat penebaran 15 ekor per wadah. Penelitian dilaksanakan secara eksperimental menggunakan rancangan acak lengkap dengan empat perlakuan dan tiga ulangan. Perlakuan terdiri atas perlakuan A (kontrol), yaitu tanpa penambahan bioflok, perlakuan $\mathrm{B}$, yaitu penambahan bioflok $10 \mathrm{~mL}$ dan $5 \%$ pakan komersil, perlakuan $\mathrm{C}$, yaitu penambahan bioflok $15 \mathrm{~mL}$ dan $5 \%$ pakan komersil, dan perlakuan $\mathrm{D}$, yaitu penambahan bioflok $15 \mathrm{~mL}$ dan tanpa penambahan pakan komersil. Parameter yang diamati pada akhir masa pemeliharaan meliputi laju pertumbuhan rata-rata spesifik harian, pertambahan panjang mutlak, dan kelangsungan hidup, yang kemudian diolah dengan menggunakan analisis variansi satu-faktor dengan taraf nyata 0,05 . Hasil penelitian menunjukkan bahwa penambahan bioflok berpengaruh nyata terhadap laju pertumbuhan rata-rata spesifik harian dan pertambahan panjang mutlak. Perlakuan B menghasilkan laju pertumbuhan rata-rata spesifik harian tertinggi, yaitu $0,55 \pm 0,02 \%$ per hari, dan pertambahan panjang mutlak tertinggi, yaitu $3,7 \pm 0,1 \mathrm{~cm}$. Namun demikian, penambahan bioflok tidak memberikan pengaruh yang nyata terhadap kelangsungan hidup benih udang windu.
\end{abstract}

Kata kunci: Bioflok; Kelangsungan hidup; Laju pertumbuhan rata rata spesifik harian

\begin{abstract}
This research aims to determine the influence of the addition of biofloc on the growth and survival rate of tiger shrimp juvenile. The research was carried out for 30 days from June to July 2016 in the aquaculture laboratory of Almuslim Bireuen University. The maintenance container used was an aquarium with a size of $50 \times 30 \times 40 \mathrm{~cm}^{3}$ that contains $10 \mathrm{~L}$ with stocking density 15 tiger shrimp juvenile per aquarium. The research was carried out experimentally using a complete randomized design with four treatments and three replicates. The treatments consist of treatment $A$ (control) which has no addition of biofloc, treatment $B$ which addition of $10 \mathrm{~mL}$ biofloc and $5 \%$ of commercial feed, treatment $C$ which addition of $15 \mathrm{~mL}$ biofloc and 5\% commercial feed, and treatment $D$ which addition of $15 \mathrm{~mL}$ biofloc without commercial feed. The parameters observed at the end of the maintenance period include daily specific growth rate, absolute length increase, and survival, which were then analyzed by using a one-factor analysis of variance with a significance level of 0.05 . The results showed that the addition of biofloc significantly influenced the daily specific growth rate and the absolute length increase. Treatment $B$ gave the highest daily specific growth rate of $0.55 \pm 0,02 \%$ per day, and the highest absolute length increase of $3.7 \pm 0,1 \mathrm{~cm}$. However, the addition of biofloc has no significant influence on the survival of tiger shrimp seeds.
\end{abstract}

Keywords: Biofloc; Specific growth rate; Survival

Permalink/DOI: http://dx.doi.org/10.15408/kauniyah.v11i1. 4862 


\section{PENDAHULUAN}

Provinsi Aceh merupakan salah satu provinsi dengan produksi udang windu (Penaeus monodon) terbesar di Indonesia (Kementerian Kelautan dan Perikanan, 2014). Sentra produksi udang windu di Provinsi Aceh tersebar di wilayah Peudada (Kabupaten Bireuen), Peunteud (kotamadya) Lhokseumawe, Panton Labu (Kabupaten Aceh Utara) dan Idi (Kabupaten Aceh Timur). Budidaya udang windu mengalami perkembangan yang cukup baik dan menjadi idola pembudidaya disekitar tahun 1990-an. Adanya konflik bersenjata, kerusakan lingkungan dan penyebaran penyakit udang, menyebabkan usaha budidaya udang windu Provinsi Aceh sempat mengalami penurunan. Sampai saat ini, usaha budidaya udang windu di Aceh masih didominasi teknologi tradisional sehingga hasil panen yang diperoleh dinilai belum cukup maksimal. Hasil produksi ditahun 2011 mencapai 752 ton dan meningkat $27,5 \%$ pada tahun 2014 menjadi 1,528 ton (Kementerian Kelautan dan Perikanan, 2014).

Semakin terbatasnya sumber daya alam seperti air dan lahan, menjadikan intensifikasi sebagai pilihan yang paling memungkinkan dalam meningkatkan produksi budidaya. Berbagai upaya untuk mengembangkan perikanan budidaya terutama pada sistem intensif hingga kini masih terus dilakukan mengingat sistem tersebut masih terkendala oleh berbagai masalah di antaranya buangan limbah akuakultur, penggunaan tepung ikan sebagai bahan baku pakan buatan serta penyebaran penyakit (Food Agriculture Organization, 2007).

Salah satu upaya meningkatkan produksi udang windu adalah dengan mengurangi dampak negatif limbah budidaya terhadap lingkungan. Teknologi bioflok menjadi salah satu alternatif pemecah masalah limbah budidaya intensif. Teknologi bioflok mampu menyediakan pakan tambahan berprotein untuk hewan budidaya sehingga dapat meningkatkan pertumbuhan, selain itu teknologi ini juga efektif menurunkan limbah nitrogen anorganik dari sisa pakan dan kotoran (Avnimelech, 2009). Penerapan teknologi bioflok memiliki prinsip memanfaatkan limbah ammonia dan nitrit pada kolam budidaya menjadi bahan pakan alami dengan bantuan bakteri hetero- trofik. Walaupun demikian, proses penyerapan nitrogen anorganik oleh bakteri hanya terjadi ketika rasio $\mathrm{C} / \mathrm{N}$ lebih tinggi dari sepuluh (Ma'in et al., 2013). Sisa pakan yang ada di media pemeliharaan dimanfaatkan oleh bakteri heterotrof untuk diasimilasi nitrogen dan karbon anorganiknya menjadi protein mikroba sehingga dapat dimanfaatkan sebagai pakan alami udang windu (Avnimelech \& Kochba, 2009).

De Schryver et al. (2008) melaporkan bahwa bakteri flok tersusun atas campuran berbagai jenis mikroorganisme (bakteri pembentuk flok, bakteri filamen, dan fungi). Beberapa penelitian menunjukkan bahwa aplikasi teknologi bioflok berperan dalam perbaikan kualitas air, peningkatan biosekuriti, peningkatan produktivitas dan efisiensi pakan serta penurunan biaya produksi melalui penurunan biaya pakan (Avnimelech \& Kochba, 2009; Hari et al., 2006; Kuhn et al., 2009). Sopian et al. (2013) membuktikan bahwa aplikasi teknologi bioflok dapat meningkatkan kelangsungan hidup larva udang galah (Macrobrachium rosenbergii) dengan tingkat kelangsungan hidup terbaik diperoleh dengan penamahan bioflok sebanyak $5 \mathrm{~mL}$. Teknologi bioflok juga berhasil meningkatkan pertumbuhan panjang dan berat ikan lele pada media pemeliharaan (Utarani, 2014). Penelitian ini bertujuan untuk mengetahui pengaruh penambahan bioflok terhadap pertumbuhan dan kelangsungan benih udang windu serta pengaruhnya terhadap laju penguraian amonia pada media pemeliharaan benih udang windu.

\section{MATERIAL DAN METODE}

Penelitian ini dilaksanakan pada bulan Juni hingga Juli 2016. Tahap pemeliharaan udang windu dilakukan di Laboratorium Budidaya Perairan Universitas Almuslim. Uji parameter kimiawi air berupa amoniak, nitrit dan nitrat dilakukan di Laboratorium Central Proteina Prima, Bireuen. Penelitian diawali dengan mempersiapkan wadah kultur flok berbentuk bulat dengan kapasitas 28 liter air. Sebelum digunakan wadah disucihamakan terlebih dahulu dengan menggunakan kaporit sebanyak $150 \mathrm{mg} / \mathrm{L}$ agar terbebas dari virus dan penyakit (Tahe \& Makmur, 2016). Wadah dilengkapi aerasi untuk mempertahankan konsentrasi oksigen terlarut. Sebelum diguna- 
kan, selang aerasi, dan batu aerasi dicuci terlebih dahulu kemudian dikeringkan.

Bioflok diproduksi dengan menambahkan probiotik cair EM4 yang mengandung bakteri Bacillus sp. (bakteri inokulum pembentuk flok) sebanyak $5 \mathrm{~mL} / \mathrm{L}$ kedalam media. Molase (kandungan $\mathrm{C}=50 \%$ ) dan pupuk Zwavelzure Ammoniak (ZA) $(\mathrm{N}=21 \%)$ ditambahkan setiap hari ke dalam wadah dengan rasio $\mathrm{C}: \mathrm{N}=20: 1$. Kapur koptan atau dolomit sebanyak $1 \mathrm{mg} / \mathrm{L}$ akan ditambahkan apabila terjadi fluktuasi $\mathrm{pH}$ yang tinggi. Setelah flok terbentuk, guna mempertahankan rasio $\mathrm{C}: \mathrm{N}$ pada rasio 20:1, dilakukan penambahan molase dan pupuk ZA secara teratur (Gunarto \& Suwoyo, 2011).

Wadah kultur flok dan wadah pemeliharaan udang windu dibuat terpisah. Wadah pemeliharaan benih udang windu yang digunakan berupa akuarium dengan ukuran 50x30x40 cm sejumlah 12 unit dengan volume air masing masing wadah sebanyak $10 \mathrm{~L}$. Sebelum digunakan wadah disucihamakan terlebih dahulu supaya terbebas dari penyakit. Setiap wadah dilengkapi aerasi untuk mempertahankan konsentrasi oksigen terlarut dalam air. Air yang digunakan pada pemeliharaan udang windu adalah air payau steril dengan kisaran salinitas 15-30 ppt (SNI 01-6144-2006).

500 ekor benih udang windu dikoleksi dari Desa Bungkah Kecamatan Muara Batu Kabupaten Aceh Utara untuk digunakan sebagai biota uji. Proses sortir dilakukan untuk mendapatkan jenis dan ukuran benih yang sama. Ukuran benih yang digunakan yaitu Post Larvae (PL) 21 (Zulfahmi, 2017). Sebelum benih ditebar dalam media perlakuan, terlebih dahulu benih diaklimatisasi selama tujuh hari dengan diberi pakan komersil gold coin (kandungan protein $34 \%$, lemak $12 \%$, serat $4 \%$, abu $12 \%$ dan kadar air $6 \%$ ) sebanyak dua kali sehari secara adlibitum. Biota uji sehat dicirikan dengan bagian tubuh yang lengkap, warna tubuh cerah serta memiliki arah yang jelas dalam berenang (Arafani et al., 2016). Hanya biota uji sehat yang akan digunakan untuk perlakuan berikutnya.

Metode penelitian berupa rancangan acak lengkap dengan empat perlakuan dan tiga ulangan, perlakuan A (pemberian pakan komersil tanpa penambahan bioflok), perlaku- an B (pemberian pakan komersil dengan penambahan bioflok sebanyak $10 \mathrm{~mL}$ ) C (pemberian pakan komersil dengan penambahan bioflok sebanyak $15 \mathrm{~mL}$ ) dan $\mathrm{D}$ (penambahan bioflok sebanyak $15 \mathrm{~mL}$ tanpa pemberian pakan komersil). Padat tebar benih udang windu untuk setiap perlakuan berjumlah 15 ekor/wadah (Zulfahmi, 2017). Sistem pemberian pakan dilakukan secara selingan (selang seling). Jumlah pakan komersil yang diberikan adalah 5\% dari biomasa biota uji. Frekuensi pemberian pakan dilakukan sebanyak dua kali sehari (Febrina et al., 2016), pakan komersil diberikan setiap pagi dan sore hari pukul 08.00 WIB dan 18.00 WIB, sedangkan pemberian pakan flok hanya dilakukan pada pagi hari. Masa pemeliharaan berdurasi 30 hari tanpa pergantian air pada setiap perlakuannya.

Pengamatan yang diamati dalam penelitian ini meliputi laju pertumbuhan berat rata rata spesifik harian (SGR), pertambahan panjang mutlak dan kelangsungan hidup (SR). Laju pertumbuhan berat rata-rata spesifik harian (SGR) dihitung berdasarkan rumus Effendi (2004) sebagai berikut:

$$
\mathrm{SGR}=\left(t \sqrt{\frac{w t}{w o}}-1\right) \times 100
$$

Keterangan:

SGR : Laju pertumbuhan spesifik udang $(\%) /$ hari

t : Lama waktu pemeliharaan udang (hari)

Wo : Bobot rata-rata awal pemeliharaan udang (mg)

Wt : Bobot rata-rata akhir pemeliharaan udang $(\mathrm{mg})$

Pertambahan Panjang Mutlak dihitung berdasarkan rumus Effendi (2004) sebagai berikut.

$$
\mathrm{P}_{\mathrm{m}}=\mathrm{P}_{\mathrm{t}}-\mathrm{P}_{\mathrm{o}}
$$

Keterangan:

$\mathrm{P}_{\mathrm{m}} \quad$ : Pertambahan panjang mutlak

$\mathrm{P}_{\mathrm{t}} \quad$ : Panjang rata-rata individu hari ke- $\mathrm{t}$ (cm)

$\mathrm{P}_{\mathrm{o}} \quad$ : Panjang rata-rata individu hari keo $(\mathrm{cm})$

Kelangsungan Hidup (SR) dihitung berdasarkan rumus Effendi (2004) sebagai berikut: 


$$
\mathrm{SR}=\frac{N t}{N 0} \times 100
$$

Keterangan:

SR : Kelangsungan hidup udang (\%)

$\mathrm{Nt}$ : Jumlah udang yang hidup pada akhir penelitian (ekor)

No : Jumlah udang pada awal penelitian (ekor)

Pengukuran parameter fisik-kimiawi air pada media pemeliharaan dilakukan secara in situ dan ex situ setiap sepuluh hari sekali meliputi suhu, oksigen terlarut, $\mathrm{pH}$, amoniak, nitrit dan nitrat. Pengukuran suhu dilakukan dengan menggunakan termometer, oksigen terlarut diukur dengan menggunakan dissolved oxygen meter, $\mathrm{pH}$ diukur dengan menggunakan $\mathrm{pH}$ meter, sedangkan amoniak, nitrit dan nitrat diukur dengan menggunakan metode spektrofotometrik. Analisis statistik yang digunakan untuk membandingkan laju pertumbuhan rata rata spesifik harian (SGR), pertambahan panjang mutlak dan kelangsungan hidup (SR) antar perlakuan adalah ANOVA (Analisys of Varians) satu arah dengan selang kepercayaan $95 \%$.

\section{HASIL}

Penambahan bioflok dengan dosis yang berbeda berpengaruh nyata terhadap laju pertumbuhan berat rata-rata spesifik harian benih udang windu $(\mathrm{p}<0,05)$.

Laju pertumbuhan berat rata-rata spesifik harian tertinggi terdapat pada perlakuan B (penambahan flok $10 \mathrm{~mL}$ dan pakan komersil) dengan nilai pertumbuhan sebesar $0,55 \pm 0,02 \% /$ hari. Sedangkan nilai terendah terdapat pada perlakuan D (penambahan 15 $\mathrm{mL}$ flok tanpa tambahan pakan komersil) dengan nilai laju pertumbuhan berat rata-rata spesifik harian 0,28 $\pm 0,03 \% /$ hari (Tabel 1).

Penambahan bioflok juga berpengaruh nyata terhadap pertambahan panjang mutlak benih udang windu $(\mathrm{p}<0,05)$. Hasil pengamatan tertinggi terdapat pada perlakuan B yaitu sebesar $3,7 \pm 0,01 \mathrm{~cm}$, sedangkan nilai laju pertumbuhan terendah terdapat pada perlakuan D dengan nilai $2,53 \pm 0,05 \mathrm{~cm}$ (Tabel 1). Berbeda dengan laju pertumbuhan rata-rata spesifik harian dan pertambahan panjang mutlak benih udang windu. Penambahan bioflok tidak menunjukkan adanya pengaruh yang nyata tingkat kelangsungan hidup benih udang windu ( $\mathrm{p}>0,05)$. Tingkat kelangsungan hidup tertinggi benih udang windu terdapat pada perlakuan $\mathrm{B}$ dengan angka kelangsungan hidup sebesar $91,06 \pm 1,41 \%$, dan nilai terendah diperoleh pada perlakuan D sebesar $66,6 \pm 3,53 \%$.

Tabel 1. Pengaruh penambahan bioflok terhadap laju pertumbuhan berat rata rata spesifik harian, pertambahan panjang mutlak dan kelangsungan hidup benih udang windu pada setiap perlakuan

\begin{tabular}{cccc}
\hline & \multicolumn{3}{c}{ Variabel } \\
\cline { 2 - 4 } Perlakuan & $\begin{array}{c}\text { Laju pertumbuhan berat rata } \\
\text { rata spesifik harian (\%/hari) }\end{array}$ & $\begin{array}{c}\text { Pertambahan } \\
\text { panjang mutlak }(\mathrm{cm})\end{array}$ & $\begin{array}{c}\text { Kelangsungan } \\
\text { hidup (\%) }\end{array}$ \\
\hline $\mathrm{A}$ & $0,38 \pm 0,03^{\mathrm{a}}$ & $3,03 \pm 0,11^{\mathrm{a}}$ & $77,76 \pm 2,82^{\mathrm{a}}$ \\
$\mathrm{B}$ & $0,55 \pm 0,02^{\mathrm{b}}$ & $3,70 \pm 0,1^{\mathrm{b}}$ & $91,06 \pm 1,41^{\mathrm{a}}$ \\
$\mathrm{C}$ & $0,35 \pm 0,05^{\mathrm{a}}$ & $2,93 \pm 0,14^{\mathrm{a}}$ & $73,3 \pm 2,82^{\mathrm{a}}$ \\
$\mathrm{D}$ & $0,28 \pm 0,03^{\mathrm{a}}$ & $2,53 \pm 0,05^{\mathrm{ab}}$ & $66,6 \pm 3,53^{\mathrm{a}}$ \\
\hline
\end{tabular}

Keterangan: Nilai dengan super skrip yang berbeda, menunjukkan hasil yang berbeda nyata ( $p$ $<0,05$ ), A (pemberian pakan komersil tanpa penambahan bioflok), B (pemberian pakan komersil dengan penambahan bioflok sebanyak $10 \mathrm{~mL}$ ) $\mathrm{C}$ (pemberian pakan komersil dengan penambahan bioflok sebanyak $15 \mathrm{~mL}$ ) dan $\mathrm{D}$ (penambahan bioflok sebanyak $15 \mathrm{~mL}$ tanpa pemberian pakan komersil)

\section{Parameter Fisik-Kimiawi Air}

Nilai parameter fisik kimiawi air pada setiap perlakuan selama masa penelitian masih berada dalam kisaran baik untuk pemeliharaan benih udang windu. Kandungan oksigen terlarut dalam media pemeliharaan udang windu berkisar antara 5-5,6 mg/L (Tabel 2). Konsentrasi amoniak, nitrat dan nitrit pada awal penelitian tidak menunjukkan nilai yang berbeda pada setiap perlakuan. 
Selama 10 hari pengamatan, nilai amonia tertinggi terdapat pada perlakuan A (kontrol) yaitu $0,073 \mathrm{mg} / \mathrm{L}$ dan nilai amonia terendah tardapat pada perlakuan D yaitu $0,0660 \mathrm{mg} / \mathrm{L}$. Pada akhir masa pemeliharaan amonia tertinggi terdapat pada perlakuan A (kontrol) yaitu
0,1993 $\mathrm{mg} / \mathrm{L}$, dan nilai terendah terdapat pada perlakuan D yaitu $0,1520 \mathrm{mg} / \mathrm{L}$. Nilai amonia meningkat seiring bertambahnya masa pemeliharaan, namun pada perlakuan dengan penambahan bioflok, nilai amonia cenderung menurun dan lebih stabil (Gambar 1).

Tabel 2. Kisaran nilai parameter fisik kimiawi air selama masa pemeliharaan benih udang windu pada setiap perlakuan

\begin{tabular}{lccccc}
\hline \multirow{2}{*}{ Parameter } & \multirow{2}{*}{ Satuan } & \multicolumn{4}{c}{ Pengamatan (rata rata/perlakuan) } \\
\cline { 3 - 6 } & & $\mathrm{A}$ & $\mathrm{B}$ & $\mathrm{C}$ & $\mathrm{D}$ \\
\hline Suhu & ${ }^{\circ} \mathrm{C}$ & $29-30$ & $29-30$ & $29-30$ & $29-30$ \\
pH & - & $7,5-8,4$ & $7,5-8,3$ & $7,5-8,3$ & $7,5-8,4$ \\
Oksingen terlarut & $\mathrm{mg} / \mathrm{L}$ & $5,0-5,5$ & $5,1-5,6$ & $5,1-5,5$ & $5,0-5,6$ \\
Salinitas & $\mathrm{ppt}$ & $20-25$ & $20-26$ & $20-26$ & $20-25$ \\
Nitrit & $\mathrm{mg} / \mathrm{L}$ & $0,001-0,0282$ & $0,001-0,0251$ & $0,001-0,0264$ & $0,001-0,0180$ \\
Nitrat & $\mathrm{mg} / \mathrm{L}$ & $0,001-0,077$ & $0,001-0,0616$ & $0,001-0,0613$ & $0,001-0,0486$ \\
\hline
\end{tabular}

Keterangan: A (pemberian pakan komersil tanpa penambahan bioflok), B (pemberian pakan komersil dengan penambahan bioflok sebanyak $10 \mathrm{~mL}$ ) C (pemberian pakan komersil dengan penambahan bioflok sebanyak $15 \mathrm{~mL}$ ) dan $\mathrm{D}$ (penambahan bioflok sebanyak $15 \mathrm{~mL}$ tanpa pemberian pakan komersil)

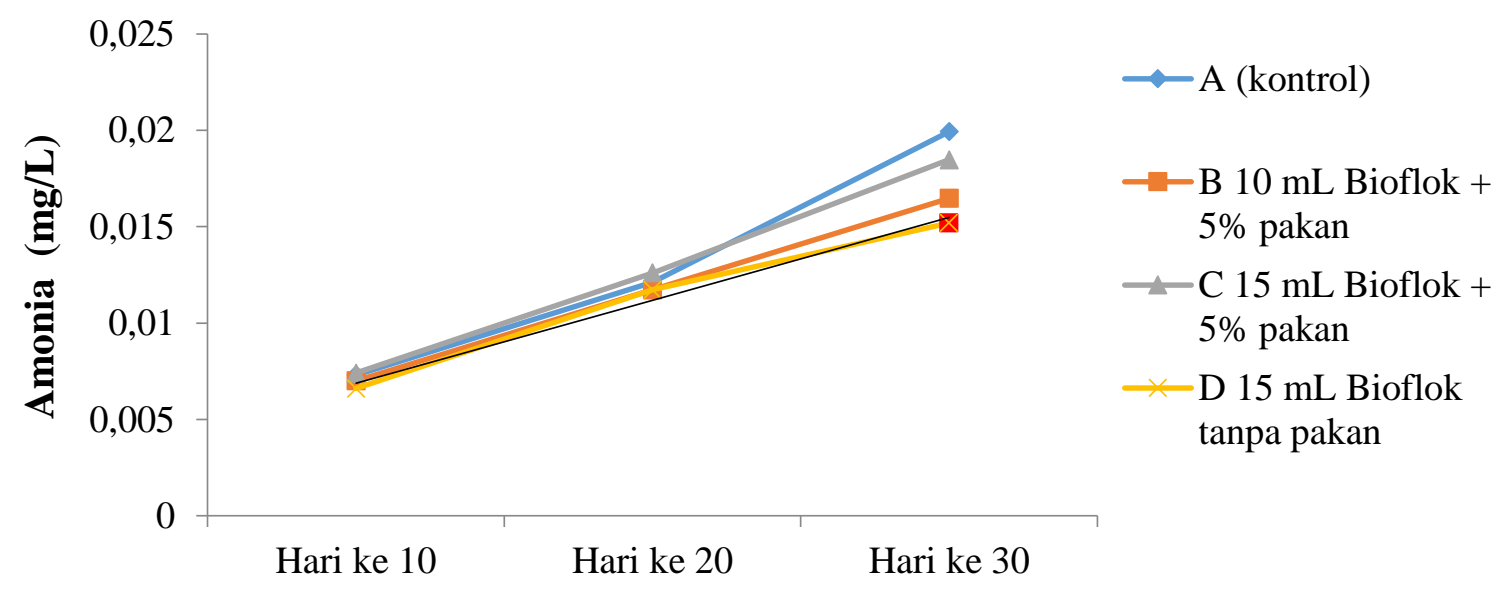

Gambar 1. Kandungan amoniak selama masa pemeliharaan benih udang windu pada setiap perlakuan

\section{PEMBAHASAN}

Teknologi bioflok terbukti sangat bermanfaat bagi usaha budidaya, baik secara ekonomis maupun ekologis (Avnimelech, 1999; De Schryver et al., 2008; Crab et al., 2007). Teknologi ini menjadi solusi pemecahan permasalahan kualitas air dengan menurunkan limbah nitrogen anorganik (Crab et al., 2007). Bioflok juga dapat dimanfaatkan sebagai sumber pakan sehingga memberikan pengaruh positif terhadap produktifitas budidaya udang windu (Burford et al., 2004).

Pemberian bioflok berpengaruh nyata terhadap laju pertumbuhan berat rata-rata spesifik harian dan pertambahan panjang benih benih udang windu $(\mathrm{p}<0,05)$. Laju pertumbuhan berat rata-rata spesifik harian dan pertambahan panjang tertinggi didapat pada perlakuan B masing masing sebesar $0,55 \pm 0,02 \% /$ hari dan $3,7 \pm 0,01 \mathrm{~cm}$. Terjadinya pertumbuhan berat dan panjang yang tinggi tersebut diduga karena adanya suplai pakan tambahan dari flok yang ada dalam wadah pemeliharaan. Adanya tambahan pakan alami pada media, berasal dari asimilasi nitrogen dan carbon anorganik menjadi protein mikroba bakteri heterotrof yang telah ditambahkan ke dalam media pemeliharaan (De Schryver et al., 
2008). Komunitas bakteri yang terakumulasi di dalam sistem akuakultur heterotrofik akan membentuk flok (gumpalan) yang bermanfaat sebagai sumber pakan tambahan untuk biota budidaya (Crab et al., 2007). Aplikasi bioflok mampu menyebabkan tingkat efisiensi pemanfaatan pakan menjadi lebih tinggi, disamping juga meningkatkan laju pertumbuhan berat dan panjang (Widanarni et al., 2008).

Penambahan bioflok tidak menunjukkan adanya pengaruh yang nyata terhadap tingkat kelangsungan hidup benih udang windu ( $p>0,05)$. Ini menunjukkan adanya reaksi positif dari benih udang terhadap keberadaan flok dan pakan. Tingkat kelangsungan hidup tertinggi benih udang windu terdapat pada perlakuan $B$ dengan tingkat kelangsungan hidup sebesar $91,06 \pm 1,41 \%$. Hal ini senada dengan penelitian yang dilakukan Rangka dan Gunarto (2012) yang menyatakan bahwa pemberian flok tidak pengaruh yang nyata terhadap tingkat kelangsungan hidup benih udang vaname (Litopenaeus vannamei) dengan kisaran tingkat kelangsungan hidup berada pada rentang 66-92\%. Media pemeliharaan yang menerapkan aplikasi bioflok juga menunjukkan kondisi lebih baik dan relatif ideal untuk pendederan benih ikan Lele (Clarias gariepinus). Hal ini ditandai dengan relatif rendahnya tingkat kematian benih selama pemeliharaan (Teguh et al., 2014).

Pengukuran kualitas air merupakan faktor penting untuk meningkatkan produktivitas flok dalam media. Nilai kisaran parameter fisik kimiawi air selama penelitian masih berada dalam kisaran baik untuk mendukung pertumbuhan flok. Kandungan oksigen terlarut selama penelitian berada pada kisaran 5,0-5,6 mg/L. Ma'in et al. (2013) menyatakan bahwa konsentrasi oksigen terlarut pada media pemeliharaan harus selalu terpenuhi disebabkan bioflok terbentuk pada kondisi aerob.

Pemeliharaan dengan penambahan bioflok memberikan nilai lebih dibandingkan pemeliharaan tanpa bioflok, dengan kualitas air yang terkontrol sehingga tidak perlu melakukan pergantian air (Sopian et al., 2013). Hal ini dibuktikan dengan rendahnya nilai amoniak pada perlakuan D dibandingkan dengan perlakuan A (Kontrol) pada akhir masa pemeliharaan. Nilai amoniak pada perlakuan D yaitu $0,1520 \mathrm{mg} / \mathrm{L}$ sedangkan perlakuan A (kontrol) yaitu $0,1993 \mathrm{mg} / \mathrm{L}$. Penambahan flok kedalam wadah pemeliharaan mampu menekan kadar amonia dalam air sehingga amonia tidak mengalami peningkatan yang signifikan (De Schryver et al., 2008; Husain et al., 2014). Gunadi dan Hafsaridewi (2007) menyatakan bahwa proses mikrobiologi yang terjadi selama pembentukan flok dapat meningkatkan kualitas air dan mengurangi beban cemaran limbah budidaya ke perairan. Sistem heterotrofik mempunyai potensi untuk diterapkan dalam pemanfaatan limbah amonia pada pemeliharaan ikan.

Nilai parameter kualitas air lainnya yang meliputi suhu, $\mathrm{pH}$, oksigen terlarut, nitrat dan nitrit masih berada dalam ambang batas optimum untuk pemeliharaan benih udang windu. Udang windu memiliki kisaran toleransi suhu yang lebar dibandingkan dengan jenis udang lainnya. Pillay dan Kutty (2005) menyatakan bahwa kisaran toleransi optimum untuk pemeliharaan udang windu berkisar 12 ${ }^{\circ} \mathrm{C}$ sampai $37,5{ }^{\circ} \mathrm{C}$. Walupun demikian suhu yang terlalu tinggi dapat menggangu pembentukan flok di media (De Schryver \& Verstraete, 2009).

Oksigen terlarut merupakan salah satu parameter yang penting diperhatikan dalam media pemeliharaan udang windu menggunakan aplikasi bioflok. Aerasi digunakan untuk menjaga agar nilai oksigen terlarut tetap berada pada kisaran optimum. Hargreaves (2013) menyatakan bahwa dalam sistem bioflok, aerasi juga dibutuhkan guna proses pengadukan air dan mencegah terjadinya pengendapan bioflok, sisa pakan dan feses ikan yang dapat berakibat pada meningkatnya amoniak. Kandungan amoniak dalam media pemeliharaan ikut dipegaruhi oleh nilai $\mathrm{pH}$. Ebeling et al. (2006) menambahkan bahwa $\mathrm{pH}$ merupakan salah satu parameter yang mempengaruhi tingkatan amoniak terionisasi dan amoniak tak terionisasi didalam air.

Menurut Taslihan et al. (2003) kandungan maksimum nitrit yang disarankan untuk pemeliharaan udang windu adalah $0,2 \mathrm{mg} / \mathrm{L}$. Hasil penelitian menunjukkan bahwa perlakuan dengan menggunakan aplikasi bioflok menunjukkan kisaran kandungan nitrit yang disarankan dibandingkan dengan perlakuan kontrol. Menurut Fast dan Lester (1992) kan- 
dungan nitrat akan menjadi toksik apabila melebihi $1 \mathrm{mg} / \mathrm{L}$. Kandungan nitrat dalam media pemeliharaan berasal dari proses nitrifikasi nitrit menjadi nitrat oleh bakteri nitrifikasi (Stickney, 2005). Rendahnya kandungan nitrit pada perlakuan bioflok menurut Ebeling et al. (2006) disebabkan oleh pemanfaatan nitrit dan nitrat tersebut oleh bakteri sebagai sumber nutrien untuk pertumbuhannya.

\section{SIMPULAN}

Pemberian bioflok berpengaruh nyata terhadap laju pertumbuhan berat rata-rata spesifik harian dan pertambahan panjang benih benih udang windu $(p<0,05)$. Laju pertumbuhan berat dan panjang tertinggi didapat pada perlakuan B (pemberian pakan komersil dengan penambahan bioflok sebanyak $10 \mathrm{~mL}$ ) masing masing sebesar $0,55 \pm 0,02 \% /$ hari dan $3,7 \pm 0,01 \mathrm{~cm}$. Penambahan bioflok tidak menunjukkan adanya pengaruh yang nyata terhadap tingkat kelangsungan hidup benih udang windu ( $p>0,05)$. Penambahan bioflok mampu menekan kadar amonia dalam media pemeliharaan benih udang Windu. Kadar amoniak terendah pada akhir masa pemeliharan terdapat perlakuan D yaitu sebesar 0,1520 mg/L.

\section{REFERENSI}

Arafani, L., Ghazali, M., \& Ali, M. (2016). Pelacakan virus bercak putih pada udang vaname (Litopenaeus vannamei) di Lombok dengan Real-Time Polymerase Chain Reaction. Jurnal Veteriner, 17(1), 88-95.

Avnimelech, Y. (1999). Carbon/nitrogen ratio as control element in aquaculture systems. Aquaculture, 176(3), 227-235.

Avnimelech, Y. (2009). Biofloc technology. A practical guide book. Baton Rouge, Louisiana, Amerika Serikat: The World Aquaculture Society.

Avnimelech, Y., \& Kochba, M. (2009). Evaluation of nitrogen uptake and excretion by tilapia in biofloc tanks, using $15 \mathrm{~N}$ tracing. Aquaculture, 287(1), $163-168$

Burford, M. A., Thompson, P. J., McIntosh, R. P., Bauman, R. H., \& Pearson, D. C., (2004). The contribution of flocculated material to shrimp (Litopenaeus vannamei) nutrition in a high intensity, zero-exchange system. Aquaculture, 232(1), 525-537.

Crab, R., Avnimelech, Y., Defoirdt T, Bossier, P., \& Verstraete, W. (2007). Nitrogen removal techniques in aquaculture for sustainable production. Aquaculture, 270(4), 1-14.

De Schryver, P., Crab, R., Defoirdt, T., Boon, N., \& Verstraete, W. (2008). The basics of bioflocs technology: the added value for aquaculture. Aquaculture, 277(3), 125-137.

De Schryver, P., \& Verstraete, W. (2009). Nitrogen removal from aquaculture pond water by heterotrophic nitrogen assimilation in lab-scale sequencing batch reactors. Biorecource Technology, 100(3), 1162-1167.

Ebeling, J. M., Timmons, M. B., Bisogni, J. J. (2006). Engineering analysis of the stoichiometry of photoautotrophic, autotrophic, and heterotrophic removal of ammonia-nitrogen in aquaculture systems. Aquaculture, 257(1), 346-358.

Effendi, I. (2004). Pengantar akuakultur. Jakarta: Penebar Swadaya.

Food Agriculture Organization. (2007). The state of world fisheries and aquaculture. Rome: FAO.

Fast, A. W., \& Lester, L. J. (1992). Marine shrimp culture: principles and practices. Amsterdam: Elsevier Science Publisher. $866 \mathrm{pp}$.

Febrina, L., Handaka, A. A., Suryana, \& Riyantini, I. (2016). Analisis optimasi faktor-faktor produksi dan pendapatan usaha budidaya udang windu di Kecamatan Cilebar Kabupaten Karawang. Jurnal Perikanan Kelautan, 7(2), 128-139.

Gunadi, B., \& Hafsaridewi, R. (2007). Pemanfaatan limbah budidaya ikan lele (Clarias gariepenus) intensif dengan sistem heterotrofik untuk pemeliharaan ikan nila. Laporan Akhir Kegiatan Riset 2007 Sukamandi: Loka Riset Pemuliaan dan Teknologi Budidaya Perikanan Air tawar.18 pp.

Gunarto \& Suwoyo, H. S. (2011). Produksi bioflok dan nilai nutrisinya dalam skala laboratorium. Prosiding Forum Inovasi Teknologi Akuakultur, 1009-1018. 
Hari, B., Kurup, B. M., Varghese, J. T., Schrama, J. W., \& Verdegem, M. C. J. (2006). The effect of carbohydrate addition on water quality and the nitrogen budget in extensive shrimp culture sistems. Aquaculture, 252(1), 248-263.

Hargreaves, J. A. (2013). Biofloc production system for aquaculture. Southern Regional Aquaculture Center: Publication factual sheet No: 4503. 12 pp.

Husain, N., Putri, B., \& Supono. (2014). Perbandingan karbon dan nitrogen pada sistem bioflok terhadap pertumbuhan nila merah (Oreochromis niloticus). Jurnal Rekayasa dan Teknologi Budidaya Perairan, 3(1), 343-350.

Kementerian Kelautan dan Perikanan. (2014). SDM dan IPTEK kunci sukses industrialisasi berbasis perikanan budidaya. Jakarta: Kementerian Kelautan dan Perikanan.

Kuhn, D. D., Boardman, G. D., Lawrence, A. L, Marsh, L., \& Flick, G. J. (2009). Microbial floc meal as a replacement ingredient for fish meal and soybean protein in shrimp feed. Aquaculture, 296, 51-57.

Ma'in, Anggoro, S., \& Sasongko, S. B. (2013). Kajian dampak lingkungan penerapan teknologi bioflok pada kegiatan budidaya udang vaname dengan metode Life Cycle Assessment. Jurnal Ilmu Lingkungan, 11(2), 110-119.

Pillay, T. V. R., \& Kutty, M. N. (2005). Aquaculture: principles and practices. Second edition. Iowa, USA: Blackwell Publishing. 640 pp.

Rangka, N. A., \& Gunarto. (2012), Pengaruh penumbuhan bioflok pada budidaya udang vaname pola intensif di tambak. Jurnal Ilmiah Perikanan dan Kelautan, 4(2), 141-149.
Stickney, R. R. (2005). (Aquaculture: An Introductory Text. Massachusetts: CABI Publication. 265 pp.

Sopian, A., Ikhsan, K., \& Fajar, A. (2013). Pemanfaatan bioflok dari media pendederan untuk pemeliharaan larva udang galah (Macrobrachium rosenbergii). Widyariset, 16(2), 277-282.

Tahe, S., \& Makmur. (2016). Pengaruh padat penebaran terhadap produksi udang vaname (Litopenaeus vannamei) superintensif skala kecil. Prosiding Forum Inovasi Teknologi Akuakultur, 303-310.

Taslihan, A., Supito, Sutikno, E., \& Callinan, R. B. (2003). Tiger prawn culture technique. Jepara: Direktorat Jenderal Perikanan Budidaya, Balai Besar Pengembangan Budidaya Air Payau. 59 pp

Teguh, E. K., Agil, H., Agung. S., \& Slamet, B. P. (2014). Pengaruh padat tebar berbeda terhadap pertumbuhan dan kehidupan benih lele (Clarias gariepinus) dalam media bioflok. Universitas Diponegoro. Journal of Aquaculture Management and Technology, 3(3), 35-42.

Utarini, S. R. (2014). Manajemen kualitas media pendederan lele pada lahan terbatas dengan teknik bioflok. Jurnal MIPA, 37(1),16-21.

Widanami, Sukenda, \& Setiawati, M. (2008). Bakteri probiotik dalam budidaya udang: seleksi, mekanisme aksi, karakterisasi, dan aplikasinya sebagai agen biokontrol. Jurnal Imu Pertanian Indonesia, 13(2), 80-89.

Zulfahmi, I. (2017). Pengaruh padat tebar berbeda terhadap pertumbuhan benih udang windu (Penaeus monodon Fabricius, 1798) yang dipelihara pada media bioflok. Scientiae Educatia: Jurnal Pendidikan Sains, 6(1), 62-66. 